\title{
Fishes from Parque Estadual de Itapeva, Rio Grande do Sul state, Atlantic Forest biome, Brazil
}

\author{
Marco A. Azevedo and Vinicius A. Bertaco* \\ Fundação Zoobotânica do Rio Grande do Sul, Museu de Ciências Naturais, Laboratório de Ictiologia. Av. Dr. Salvador França, 1427, \\ 90690-000 Porto Alegre, RS, Brazil \\ * Corresponding author. E-mail: vinicius-bertaco@fzb.rs.gov.br
}

\begin{abstract}
The ichthyofauna herein presented was collected in streams, lake, and swamps from the Parque Estadual de Itapeva, Rio Mampituba basin. The protected area is located in the northernmost part of the coastal plain of Rio Grande do Sul state. Samplings resulted in 26 species, in 20 genera, 15 families, and six orders. Two species are listed as threatened and one near threatened in Rio Grande do Sul. This study represents the first fish survey in the protected area, Atlantic Forest biome.
\end{abstract}

Key words: ichthyofauna; coastal plain; conservation unit; Rio Mampituba

\section{INTRODUCTION}

In Rio Grande do Sul state (RS) there are 23 state conservation units of public administration managed by Secretary of Environment and Sustainable Development (Secretaria do Ambiente e Desenvolvimento Sustentável, SEMA), totaling about 300,000 ha $\left(3,000 \mathrm{~km}^{2}\right)$ of protected area. Many watercourses occur in all of these protected areas and few ichthyofaunistic studies have been done to determine the number of species or to evaluate conservation status of these species. According to Reis et al. (2003a, 2003b) 325 freshwater fish species occur in Rio Grande do Sul state, but this number is likely underestimated. In the past decade dozens of new species have been described, and it is estimated that the number can exceed four hundred species (Bertaco et al. 2016).

The Parque Estadual de Itapeva (PEVA), created in December 2002 (State Decree 42.009/2002), is located in the northernmost part of the coastal plain of Rio Grande do Sul. It contains remnants of the Atlantic Forest, a biome strongly impacted by deforestation and pollution caused by increased urbanization (Menezes et al. 2007). The majority of the watercourses that are within of the limits of park, as well as in the surrounding area to the north of the conservation unit, are part of the Rio Mampituba basin.

The objective of this study is to provide an ichthyofaunistic inventory, which may eventually support future studies on fish biology and conservation of a poorly known and protected area.

\section{MATERIALS AND METHODS Study site}

The PEVA comprises mobile and fixed dunes, grasslands, marshy forest, dry forests, a lake, small streams and swamps. The protected area is a state conservation unit in the Integral Protection category, with an area of approximately 1,000 hectares located in the Atlantic Forest biome, at the Municipality of Torres, RS. The climate in the region is subtropical characterized by rainy winters and hot summers. A total of six sampling points were used in the streams, swamps and lake of the PEVA (Figures 1-2, Table 1). All these watercourses are in the Rio Mampituba basin (boundary between Rio Grande do Sul and Santa Catarina states).

\section{Data collection}

Specimens were collected between 7 to 9 December, 2005 , using a dip net $(40 \times 80 \mathrm{~cm}$ frame and $1 \mathrm{~mm}$ net mesh size), gill nets $(20 \mathrm{~m} \times 1.8 \mathrm{~m}, 2-4 \mathrm{~cm}$ between knots), casting net $(2 \mathrm{~m} \times 1.5 \mathrm{~cm}$ between knots $)$ and seine net $(10 \mathrm{~m} \times 2 \mathrm{~m}, 5 \mathrm{~mm}$ between knots). The nets were selected according to the environmental and hydrological conditions of the sampling sites. Gill nets were set for 12 to $14 \mathrm{~h}$. The fishes were collected for the management plan of PEVA under permission of the Department of Forest and Protected Areas (Departamento de Florestas e Áreas Protegidas, DEFAP) of SEMA, permit number IBAMA 02023-000282/04-82. The specimens collected were fixed in $10 \%$ formalin, preserved in $70 \%$ alcohol and later identified using Malabarba et al. (2013), Giora and Malabarba (2016) and Lucena and Soares (2016). 


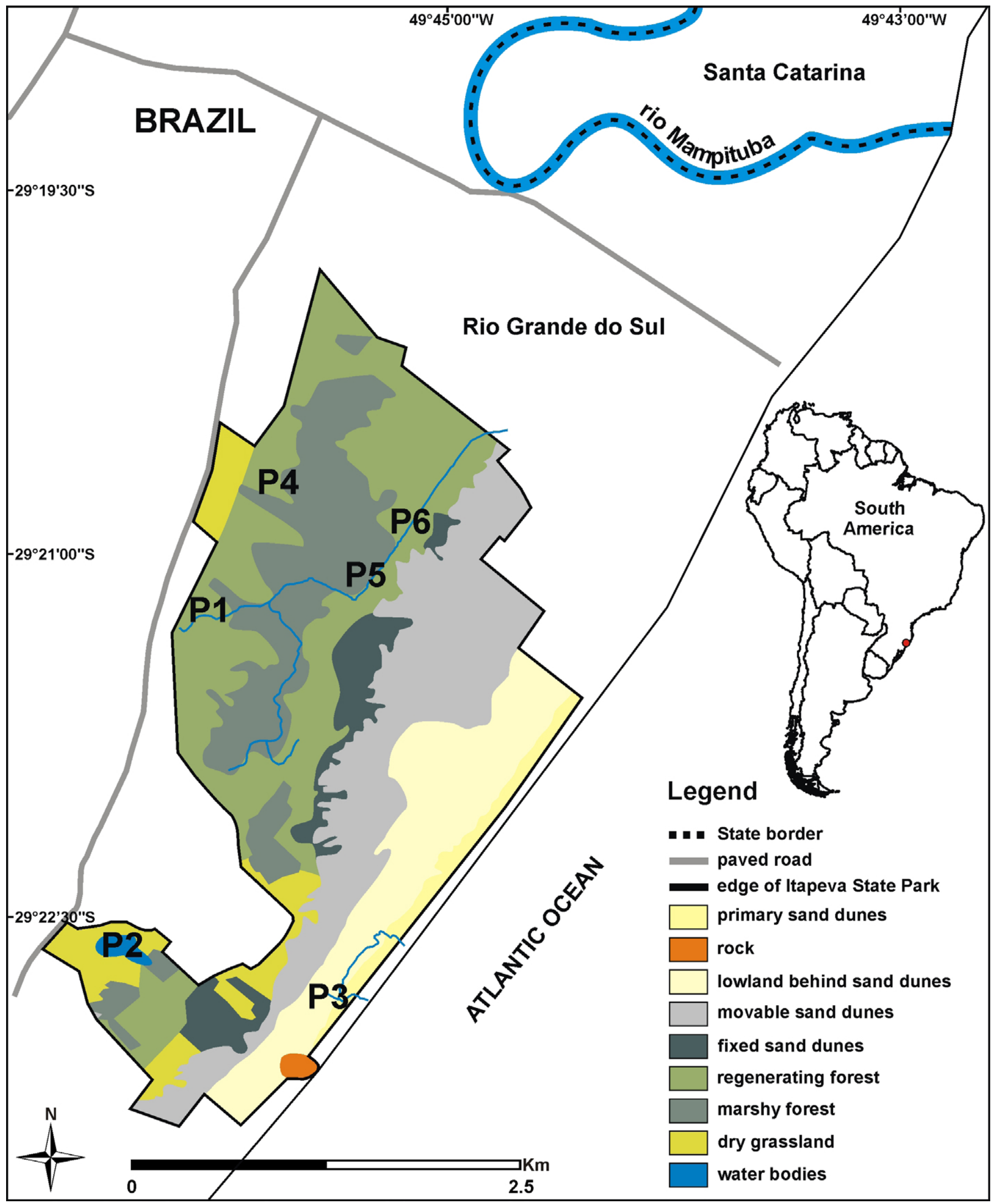

Figure 1. Study area showing the collection sites in the Parque Estadual de Itapeva, Rio Grande do Sul state, Brazil. The red dot in the South America map indicates the conservation unit.

Photos and brief diagnosis are provided for a group of species, including endangered, endemic, belonging to species complex, and recently described.

Voucher specimens are housed in the Coleção de Peixes do Museu de Ciências Naturais (MCN), Fundação Zoobotânica do Rio Grande do Sul, Porto Alegre (Table 2 ). In addition to the specimens collected during this inventory, species records from the fish collection 
Table 1. List of sampling sites and sampling methods used in the Parque Estadual de Itapeva, Torres, Rio Grande do Sul state, Brazil.

\begin{tabular}{llll}
\hline Sites & Sampling points & Coordinates & Sampling Methods \\
\hline 1 & Stream and peatland & $29^{\circ} 21^{\prime} 22^{\prime \prime} \mathrm{S}, 049^{\circ} 45^{\prime} 55^{\prime \prime} \mathrm{W}$ & Casting and dip nets \\
2 & Simão Lake & $29^{\circ} 22^{\prime} 31^{\prime \prime} \mathrm{S}, 049^{\circ} 46^{\prime} 16^{\prime \prime} \mathrm{W}$ & Gill, seine and casting nets \\
3 & Creek in eastern state park & $29^{\circ} 22^{\prime} 48^{\prime \prime} \mathrm{S}, 049^{\circ} 45^{\prime} 25^{\prime \prime} \mathrm{W}$ & Dip net \\
4 & Swamp in peatland and creek in the marshy forest & $29^{\circ} 20^{\prime} 58^{\prime \prime} \mathrm{S}, 049^{\circ} 45^{\prime} 38^{\prime \prime} \mathrm{W}$ & Dip net \\
5 & Creek in the marshy forest & $29^{\circ} 21^{\prime} 16^{\prime \prime} \mathrm{S}, 049^{\circ} 45^{\prime} 14^{\prime \prime} \mathrm{W}$ & Dip net \\
6 & Stream near wood bridge & $29^{\circ} 21^{\prime} 04^{\prime \prime} \mathrm{S}, 049^{\circ} 45^{\prime} 04^{\prime \prime} \mathrm{W}$ & Dip net \\
\hline
\end{tabular}

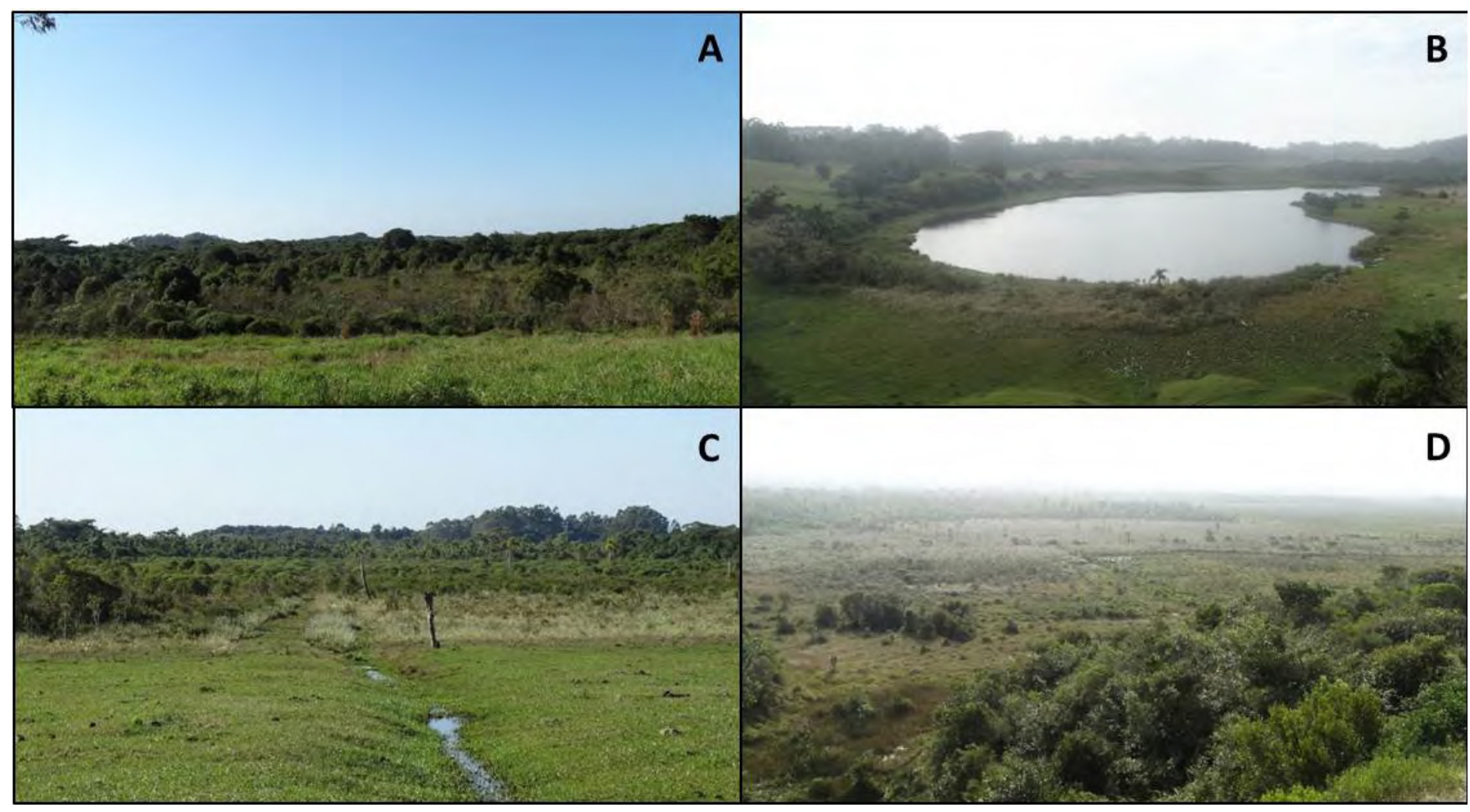

Figure 2. Sampled habitats in the Parque Estadual de Itapeva. (A) Stream and peatland (P1); (B) Simão Lake (P2); (C) Swamp in peatland and creek in marshy forest (P4); (D) Stream near wooden bridge (P6).

from the Departamento de Zoologia da Universidade Federal do Rio Grande do Sul (UFRGS), available at the SpeciesLink (http://www.splink.org.br), and the database of MCN fish collection were also used. The classification of fishes followed Reis et al. (2003a), except for Cichliformes sensu Wiley and Johnson (2010). The common names followed Malabarba et al. (2013). The respective capture habitat (e.g. "stream" for species collected in streams) for each species is given in Table 2 .

\section{RESULTS}

Four hundred and fifteen fish specimens, belonging to six orders, 15 families, 20 genera, and 26 species were collected (Figures 3-5, Table 2). All species are native to the Rio Mampituba basin. Among the specimens collected, 41.4\% were Characiformes, 25\% Cyprinodontiformes, 20\% Cichliformes, 6.7\% Siluriformes, 5.5\% Gymnotiformes, and 1\% Synbranchiformes. The most abundant species was Hyphessobrycon luetkenii (Boulenger, 1887) (17.5\%), Phalloceros spiloura Lucinda, 2008 (17.1\%), and
Geophagus brasiliensis (Quoy \& Gaimard, 1824) (13.2\%).

Most of the sampled species occurred both in streams and swamps, and four species are found only in Simão Lake (Australoheros cf. facetus (Jenyns, 1842), Cyphocharax saladensis (Meinken, 1933), Hyphessobrycon igneus Miquelarena, Menni, López \& Casciotta, 1980, and Phalloceros caudimaculatus (Hensel, 1868, Table 2). All these species prefer lentic environments typical of lakes.

Among the species collected, only two are considered threatened in RS (State Decree 51.797/ 2014), Atlantirivulus riograndensis (Costa \& Lanés, 2009) (Rivulidae) and Gymnotus refugio Giora \& Malabarba, 2016 (Gymnotidae), the latter mentioned as G. aff. pantherinus (Steindachner, 1908) in Malabarba et al. (2013). We also collected a species in the "Near Threatened" category, Mimagoniates rheocharis Menezes \& Weitzman, 1990.

The species, categorized as endangered, endemic, belonging to a species complex, recently described and/ or had the nomenclature changed, are briefly discussed below. 
Table 2. List of fish species collected in the Parque Estadual de Itapeva, Torres, Rio Grande do Sul state, Brazil and their respective capture area.

\begin{tabular}{|c|c|c|c|c|c|}
\hline ORDER/ Family/Species & Popular name & Creek Stream & Simão Lake & Swamp & Voucher \\
\hline \multicolumn{6}{|l|}{ CHARACIFORMES } \\
\hline \multicolumn{6}{|l|}{ Characidae } \\
\hline Astyanax eigenmanniorum (Cope, 1894) & Lambari-de-olho-vermelho & $\mathrm{X}$ & & & UFRGS 9449 \\
\hline Astyanax lacustris (Lütken, 1875) & Lambari-do-rabo-amarelo & $\mathrm{x}$ & & $x$ & MCN 18451 \\
\hline Hyphessobrycon boulengeri (Eigenmann, 1907) & Lambari-prata & $\mathrm{x}$ & & $\mathrm{x}$ & MCN 18472 \\
\hline Hyphessobrycon igneus Miquelarena, Menni, López \& Casciotta, 1980 & Lambari-limão & & $x$ & & MCN 18462 \\
\hline Hyphessobrycon luetkenii (Boulenger, 1887) & Lambari-vírgula & $\mathrm{X}$ & $x$ & $x$ & MCN 18464 \\
\hline Mimagoniates microlepis (Steindachner, 1877) & Lambari-azul & $\mathrm{X}$ & & $\mathrm{X}$ & MCN 18475 \\
\hline Mimagoniates rheocharis Menezes \& Weitzman, 1990 & Lambari-da-sombra & $x$ & & & MCN 18484 \\
\hline \multicolumn{6}{|l|}{ Curimatidae } \\
\hline Cyphocharax saladensis (Meinken, 1933) & Biruzinho-do-banhado & & $\mathrm{X}$ & & MCN 18461 \\
\hline \multicolumn{6}{|l|}{ Erythrinidae } \\
\hline Hoplias malabaricus (Bloch, 1794) & Traíra & $\mathrm{X}$ & & & UFRGS 8669 \\
\hline \multicolumn{6}{|l|}{ SILURIFORMES } \\
\hline \multicolumn{6}{|l|}{ Callichthyidae } \\
\hline Callichthys callichthys (Linnaeus, 1758) & Tamboatá & $\mathrm{x}$ & & $x$ & MCN 18469 \\
\hline \multicolumn{6}{|l|}{ Loricariidae } \\
\hline Otothyris rostrata Garavello, Bristki \& Schaefer, 1998 & Cascudinho-de-crista & $\mathrm{x}$ & & & MCN 18493 \\
\hline \multicolumn{6}{|l|}{ Pseudopimelodidae } \\
\hline Microglanis cibelae Malabarba \& Mahler, 1998 & Bagrinho-malhado & $\mathrm{X}$ & & & MCN 18494 \\
\hline \multicolumn{6}{|l|}{ Heptapteridae } \\
\hline Rhamdia aff. quelen (Quoy \& Gaimard, 1824) & Jundiá & $\mathrm{X}$ & & & MCN 18495 \\
\hline \multicolumn{6}{|l|}{ GYMNOTIFORMES } \\
\hline \multicolumn{6}{|l|}{ Gymnotidae } \\
\hline Gymnotus aff. carapo Linnaeus, 1758 & Tuvira-tigre & $\mathrm{X}$ & & $x$ & MCN 18477 \\
\hline Gymnotus refugio Giora \& Malabarba, 2016 & Tuvira-pantera-negra & $\mathrm{X}$ & & $\mathrm{X}$ & MCN 18476 \\
\hline \multicolumn{6}{|l|}{ Hypopomidae } \\
\hline Brachyhypopomus gauderio Giora \& Malabarba, 2009 & Tuvira-de-sela & $\mathrm{X}$ & & & MCN 18491 \\
\hline \multicolumn{6}{|l|}{ Sternopygidae } \\
\hline Eigenmannia trilineata López \& Castello, 1966 & Peixe-faca & $\mathrm{X}$ & & & MCN 18492 \\
\hline \multicolumn{6}{|l|}{ CYPRINODONTIFORMES } \\
\hline \multicolumn{6}{|l|}{ Anablepidae } \\
\hline Jenynsia multidentata (Jenyns, 1842) & Barrigudinho-listrado & $\mathrm{X}$ & & & UFRGS 8677 \\
\hline \multicolumn{6}{|l|}{ Poeciliidae } \\
\hline Phalloceros caudimaculatus (Hensel, 1868) & Barrigudinho & & $x$ & $x$ & MCN 18465 \\
\hline Phalloceros spiloura Lucinda, 2008 & Barrigudinho & $x$ & & $x$ & MCN 18468 \\
\hline \multicolumn{6}{|l|}{ Rivulidae } \\
\hline Atlantirivulus riograndensis (Costa \& Lanés, 2009) & Killifish-sulino & $\mathrm{X}$ & & $\mathrm{x}$ & MCN 18473 \\
\hline \multicolumn{6}{|l|}{ SYNBRANCHIFORMES } \\
\hline \multicolumn{6}{|l|}{ Synbranchidae } \\
\hline Synbranchus aff. marmoratus Bloch, 1795 & Muçum & $\mathrm{X}$ & & $x$ & MCN 18488 \\
\hline \multicolumn{6}{|l|}{ CICHLIFORMES } \\
\hline \multicolumn{6}{|l|}{ Cichlidae } \\
\hline Australoheros cf. facetus (Jenyns, 1842) & Cará-amarelo & & $x$ & & MCN 18459 \\
\hline Cichlasoma portalegrense (Hensel, 1870) & Cará-do-lodo & $\mathrm{X}$ & $\mathrm{X}$ & $\mathrm{X}$ & MCN 18487 \\
\hline Crenicichla lepidota Heckel, 1840 & Joaninha & $\mathrm{X}$ & $\mathrm{X}$ & $\mathrm{x}$ & MCN 18460 \\
\hline Geophagus brasiliensis (Quoy \& Gaimard, 1824) & Cará-cartola & $x$ & $x$ & & MCN 18463 \\
\hline
\end{tabular}

Phylum Chordata

Class Actinopterygii

Order Characiformes

Family Characidae

Astyanax eigenmanniorum (Cope, 1894): Figure 3A

Tetragonopterus eigenmanniorum Cope (1894): 89.

Astyanax eigenmanniorum (Cope, 1894). — Lucena et al. (2013): 549;

Malabarba et al. (2013): 29.

Material examined: Table 2
Astyanax eigenmanniorum differs from its congeners by the presence of a humeral spot forming a uniform wedge, 34 to 36 perforated scales along the lateral line, 20 to 25 branched anal-fin rays and only one maxillary tooth (Lucena et al. 2013).

Astyanax lacustris (Lütken, 1875): Figure 3B

Tetragonopterus lacustris Lütken (1875): 131.

Astyanax lacustris (Lütken, 1875). — Lucena and Soares (2016): 103. Astyanax jacuhiensis (Cope, 1894): 88. — Lima et al. (2003): 111; 

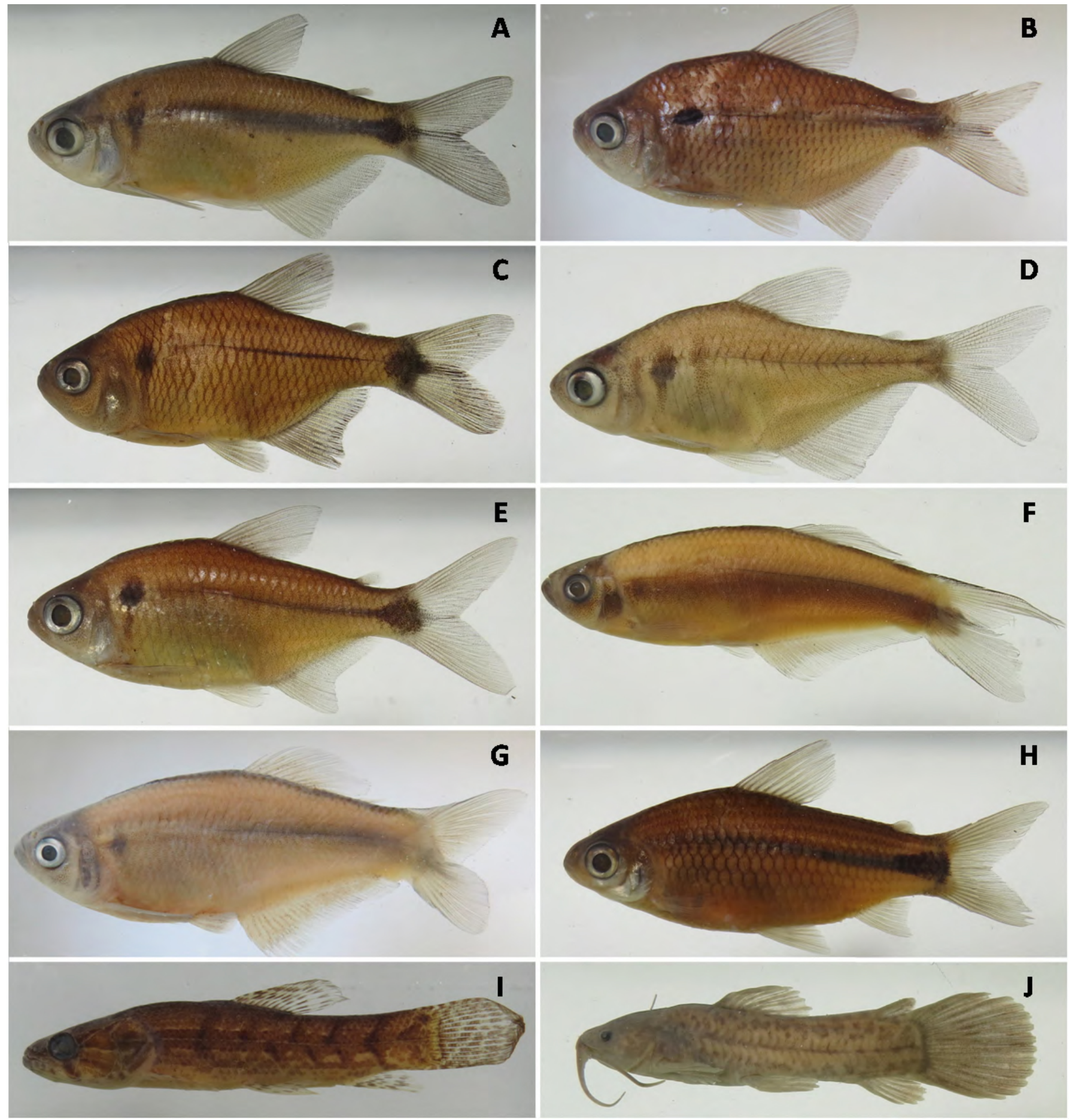

Figure 3. Species of fishes of the Parque Estadual de Itapeva, Rio Grande do Sul state, Brazil. (A) Astyanax eigenmanniorum, $46.2 \mathrm{~mm}$ SL, male, UFRGS 9449; (B) Astyanax lacustris, 50.1 mm SL, MCN 18451; (C) Hyphessobrycon boulengeri, 34.0 mm SL, MCN 18472; (D) Hyphessobrycon igneus, $29.1 \mathrm{~mm} \mathrm{SL,}$ female, MCN 18462; (E) Hyphessobrycon luetkenii, 44.1 mm SL, MCN 18464; (F) Mimagoniates microlepis, 42.2 mm SL, male, MCN 18475; (G) Mimagoniates rheocharis, 49.0 mm SL, male, MCN 18484; (H) Cyphocharax saladensis, 59.1 mm SL, MCN 18461; (I) Hoplias malabaricus, 70.0 mm SL, UFRGS 8669; (J) Callichthys callichthys, $26.0 \mathrm{~mm} \mathrm{SL}, \mathrm{MCN} 18469$.

Lucena et al. (2013): 548; Malabarba et al. (2013): 31; Lucena and Soares (2016): 103.

\section{Material examined: Table 2}

This species belongs to the $A$. bimaculatus species group (Garutti and Britski 2000) and can be distinguished from other species of this group by the absence of a conspicuous midlateral black stripe, presence of caudal peduncle spot, and absence of maxillary teeth. It was recently redescribed by Lucena and Soares (2016), and represents the only species of the group in the coastal rivers of southern Brazil.

\section{Hyphessobrycon boulengeri (Eigenmann, 1907):}

\section{Figure 3C}

Hemigrammus boulengeri Eigenmann (1907): 15.

Hyphessobrycon boulengeri (Eigenmann, 1907). - Malabarba et al. (2013): 40 
Material examined: Table 2

It may be distinguished from congeners by the presence of a vertically elongate and relatively rounded humeral spot, a narrow midlateral dark stripe on the flank, body with reticulated pattern formed by chromatophores concentrated on posterior margin of scales, and a narrow stripe on anal-fin base (Carvalho 2006).

Hyphessobrycon igneus Miquelarena, Menni, López \& Casciotta, 1980: Figure 3D

Hyphessobrycon igneus Miquelarena, Menni, López \& Casciotta (1980): 237. — Malabarba et al. (2013): 41.

Material examined: Table 2

The most distinctive characters of this species are the presence of two vertically elongate humeral spots, presence of faint black midline with some transverse bars anteriorly directed and chevron shaped along myomeres junction, and the sexual dimorphism of the color pattern (dorsal, anal and caudal fins reddish in females and yellowish in males).

Hyphessobrycon luetkenii (Boulenger, 1887): Figure 3E

Tetragonopterus luetkenii Boulenger (1887): 173.

Hyphessobrycon luetkenii (Boulenger, 1887). — Malabarba et al. (2013): 42.

Material examined: Table 2

Mimagoniates microlepis (Steindachner, 1877): Figure 3F

Paragoniates microlepis Steindachner (1877): 591.

Mimagoniates microlepis (Steindachner, 1877). - Menezes and Weitzman (2009): 355; Malabarba et al. (2013): 46; Azevedo et al. (2016): 2.

Material examined: Table 2

\section{Mimagoniates rheocharis Menezes \& Weitzman,} 1990: Figure 3G

Mimagoniates rheocharis Menezes \& Weitzman (1990): 399. Menezes and Weitzman (2009): 350; Malabarba et al. (2013): 47; Azevedo et al. (2016): 2.

Material examined: Table 2

It may be distinguished from the sympatric species Mimagoniates microlepis by the smaller number of branched anal-fin rays (usually 24-26 versus 28-31), larger number of scale rows between dorsal- and anal-fin origins (17-22 versus 14-17), and smaller number of scale rows around caudal peduncle (19-23 versus 15-18). Additionally, according to Azevedo et al. (2016), M. rheocharis and M. microlepis have the lowest absolute mean fecundity known for characids, indicating that inseminating species allocate less energy to oocyte production and reinforcing the hypothesis that insemination has an adaptive advantage, which provides a higher chance of fertilization. Category "Near Threatened" (NT) according to State Decree 51.797/ 2014.
Family Curimatidae

Cyphocharax saladensis (Meinken, 1933): Figure 3H Curimatopsis saladensis Meinken (1933): 71.

Cyphocharax saladensis (Meinken, 1933). — Malabarba et al. (2013): 54.

Material examined: Table 2

It is diagnosed from its congeners by the incomplete lateral line with 8 to 9 perforated scales, and by the presence of a conspicuous black caudal-peduncle spot.

Family Erythrinidae

Hoplias malabaricus (Bloch, 1794): Figure 3I

Esox malabaricus Bloch (1794): 149.

Hoplias malabaricus (Bloch, 1794). - Oyakawa and Mattox (2009):

119; Malabarba et al. (2013): 57.

Material examined: Table 2

Order Siluriformes

Family Callichthyidae

Callichthys callichthys (Linnaeus, 1758): Figure 3J

Silurus callichthys Linnaeus (1758): 307.

Callichthys callichthys (Linnaeus, 1758). - Malabarba et al. (2013): 64.

Material examined: Table 2

Family Loricariidae

Otothyris rostrata Garavello, Bristki \& Schaefer, 1998: Figure 4A

Otothyris rostrata Garavello, Bristki \& Schaefer (1998): 10. — Garavello et al. (1998): 4; Malabarba et al. (2013): 80

Material examined: Table 2

Family Pseudopimelodidae

Microglanis cibelae Malabarba \& Mahler, 1998:

Figure 4B

Microglanis cibelae Malabarba \& Mahler (1998): 249. — Bertaco and Cardoso (2005): 65; Malabarba et al. (2013): 87.

Material examined: Table 2

Microglanis cibelae is the most elongate Microglanis species from southern Brazil and exhibits almost completely black pectoral- and pelvic-fins (Malabarba and Mahler 1998). It differs from congeners in southern Brazil by having smaller head length (25.1-28.9\% versus 29.6-33.5\% SL in M. cottoides), smaller mouth width (50.5-65.2\% versus $67.3-84.4 \%$ HL in M. eurystoma), and smaller body width (22.3-26.0\% versus $29.3-33.1 \%$ SL in M. malabarbai) (Bertaco and Cardoso 2005).

Family Heptapteridae

Rhamdia aff. quelen (Quoy \& Gaimard, 1824):

Figure 4C

Pimelodus quelen Quoy \& Gaimard (1824): 228.

Rhamdia quelen (Quoy \& Gaimard, 1824). — Silfvergrip (1996): 95; 

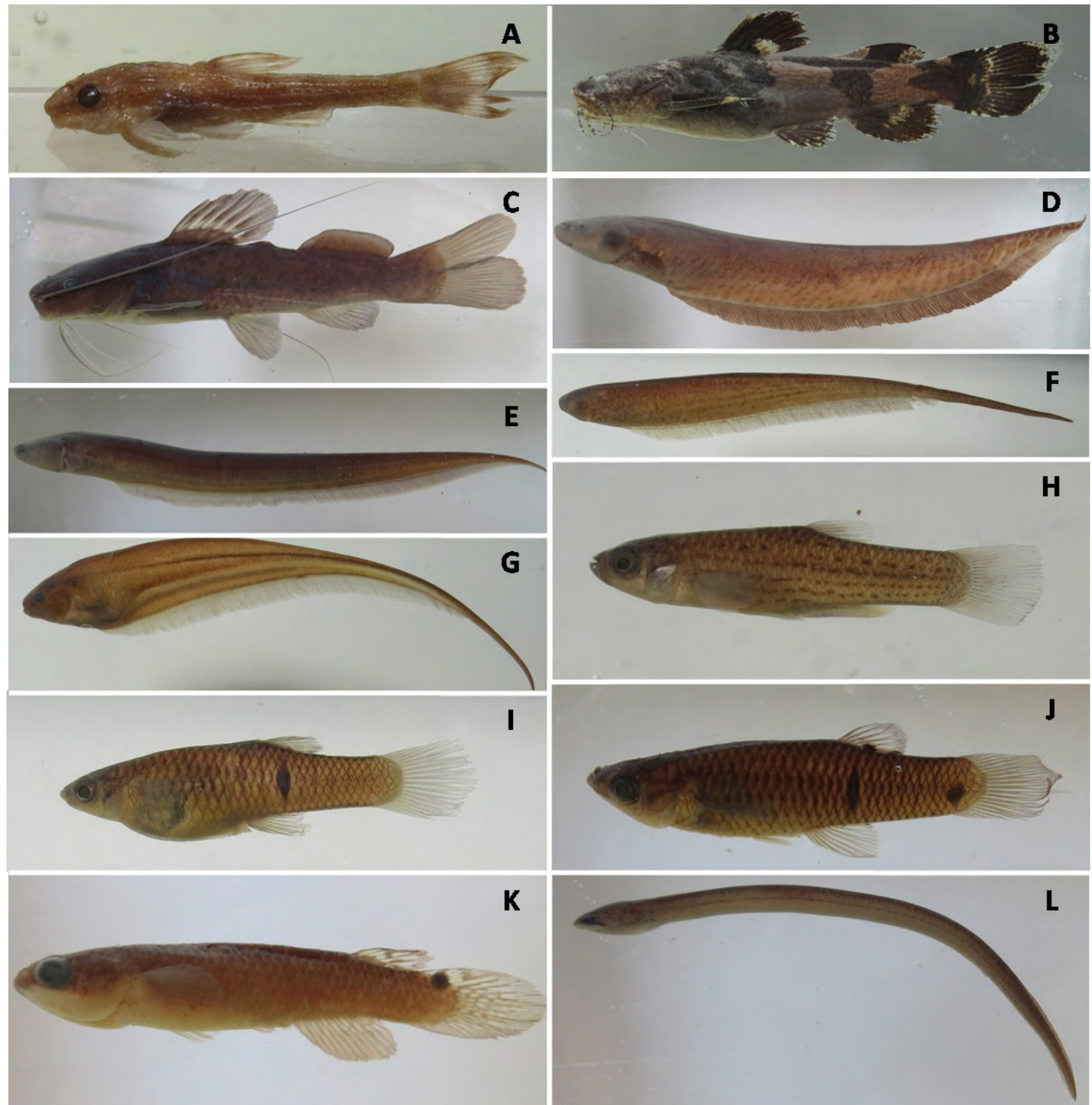

Figure 4. Species of fishes of the Parque Estadual de Itapeva, Rio Grande do Sul state, Brazil. (A) Otothyris rostrata, $25.1 \mathrm{~mm} \mathrm{SL,} \mathrm{MCN} \mathrm{18493;} \mathrm{(B)} \mathrm{Microgla-}$ nis cibelae, $44.2 \mathrm{~mm} \mathrm{SL}, \mathrm{MCN}$ 18494; (C) Rhamdia aff. quelen, $118.0 \mathrm{~mm} \mathrm{SL}, \mathrm{MCN} 18495$; (D) Gymnotus aff. carapo, $183.0 \mathrm{~mm}$ TL, MCN 18477; (E) Gymnotus refugio, $125.0 \mathrm{~mm}$ TL, MCN 18476; (F) Brachyhypopomus gauderio, $111.0 \mathrm{~mm}$ TL, MCN 18491; (G) Eigenmannia trilineata, $125 \mathrm{~mm}$ TL, MCN 18492; (H) Jenynsia multidentata, $27.2 \mathrm{~mm}$ SL, male, UFRGS 8677; (I) Phalloceros caudimaculatus, $33.0 \mathrm{~mm} \mathrm{SL}$, female, MCN 18465; (J) Phalloceros spiloura, $32.0 \mathrm{~mm}$ SL, female, MCN 18468; (K) Atlantirivulus riograndensis, 26.0 mm SL, female, MCN 18473; (L) Synbranchus aff. marmoratus, 85.0 mm TL, MCN 18488.

Ferraris (2007): 200; Malabarba et al. (2013): 73.

Material examined: Table 2

Rhamdia quelen belongs to one of the largest species complexes of fishes and is widely distributed in the Neotropical region. The coastal populations of Rhamdia from southern Brazil have distinct features and probably represent a new species (Malabarba et al. 2013).
Order Gymnotiformes

Family Gymnotidae

Gymnotus aff. carapo Linnaeus, 1758: Figure 4D Gymnotus aff. carapo Linnaeus (1758): 246. - Albert and Crampton (2003): 7; Malabarba et al. (2013): 94.

Material examined: Table 2 
This species belongs to a species complex and is widely distributed in South America (Albert and Crampton 2003). According to these authors, G. carapo stricto sensu is from Surinam, and differs from all members of the group by having 16-27 (mean = 22) dark pigment bands obliquely oriented or band-pairs, with irregular wavy margins, often broken into spots above lateral line on anterior half of body. It is possible that the coastal populations of $G$. carapo from southern Brazil is a new species (Albert and Crampton 2003).

Gymnotus refugio Giora \& Malabarba, 2016: Figure 4E Gymnotus refugio Giora \& Malabarba (2016): 583.

Gymnotus aff. pantherinus (non Steindachner, 1908). - Malabarba et al. (2013): 95.

Material examined: Table 2

This species was recently described by Giora and Malabarba (2016) from coastal rivers of Rio Grande do Sul and Santa Catarina states. It belongs to the $G$. pantherinus species-group and it is distinguished from other group members by its yellow to dark brown ground color with thick and/or vermiculated spots from the anal-fin base to the lateral line. Category "Endangered" (EN) according to State Decree 51.797/ 2014.

Family Hypopomidae

Brachyhypopomus gauderio Giora \& Malabarba, 2009: Figure 4F

Brachyhypopomus gauderio Giora \& Malabarba (2009): 62. — Malabarba et al. (2013): 97.

Material examined: Table 2

Family Sternopygidae

Eigenmannia trilineata López \& Castello, 1966:

Figure 4G

Eigenmannia trilineata López \& Castello (1966): 8. - Malabarba et al. (2013): 98

Material examined: Table 2

Order Cyprinodontiformes

Family Anablepidae

Jenynsia multidentata (Jenyns, 1842): Figure 4H

Lebias multidentata Jenyns (1842): 117

Jenynsia multidentata (Jenyns, 1842). — Malabarba et al. (2013): 102

Material examined: Table 2

Family Poeciliidae

Phalloceros caudimaculatus (Hensel, 1868): Figure 4I Girardinus caudimaculatus Hensel (1868): 362.

Phalloceros caudimaculatus (Hensel, 1868). — Lucinda (2008): 121; Malabarba et al. (2013): 106.

Material examined: Table 2
Phalloceros spiloura Lucinda, 2008: Figure 4J

Phalloceros spiloura Lucinda (2008): 150. - Bonato and Ferrer (2013): 1545; Malabarba et al. (2013): 107.

Material examined: Table 2

According to Lucinda (2008) Phalloceros spiloura is diagnosed from congeners by having a rounded spot located on the lower half of the caudal peduncle close to the base of the lowest caudal-fin rays, a patch of dark pigmentation on the last anal-fin ray of females, and the halves of gonopodial paired appendix straight and perpendicular to ray 3. It was described from coastal drainages of Rio Grande do Sul and Santa Catarina states, rio Uruguay and rio Iguaçu, and recently its geographic distribution was extended to Laguna dos Patos system (Bonato and Ferrer 2013).

Family Rivulidae

Atlantirivulus riograndensis (Costa \& Lanés, 2009): Figure 4K

Rivulus riograndensis Costa \& Lanés (2009): 92.

Atlantirivulus riograndensis (Costa \& Lanés, 2009). - Costa (2011): 244; Malabarba et al. (2013): 110.

Material examined: Table 2

This is the only species of the genus occurring in southern Brazil and differs from congeners by having dark brown dots over the dorsal portion of the flank and dorsum in females. Females have a small dark gray spot on the dorsal portion of caudal-fin base. Category "Endangered” (EN) according to State Decree 51.797/2014.

Order Synbranchiformes

Family Synbranchidae

Synbranchus aff. marmoratus Bloch, 1795: Figure 4L Synbranchus marmoratus Bloch (1795): 87. — Favorito et al. (2005): 321; Malabarba et al. (2013): 133.

Material examined: Table 2

This species belongs to a species complex and is widely distributed in river drainages from Mexico to northern Argentina. It can be distinguished from its congeners by the color pattern which consists of more homogeneously distributed spots and marbled pattern along body, and by the number of vertebrae (116-150) (Favorito et al. 2005).

Order Cichliformes

Family Cichlidae

Australoheros cf. facetus (Jenyns, 1842): Figure 5A Chromis facetus Jenyns (1842): 104.

Australoheros facetus (Jenyns, 1842): 104. - Ǩícan and Kullander (2008): 4; Malabarba et al. (2013): 120.

Material examined: Table 2

This species belongs to the Australoheros facetus group 

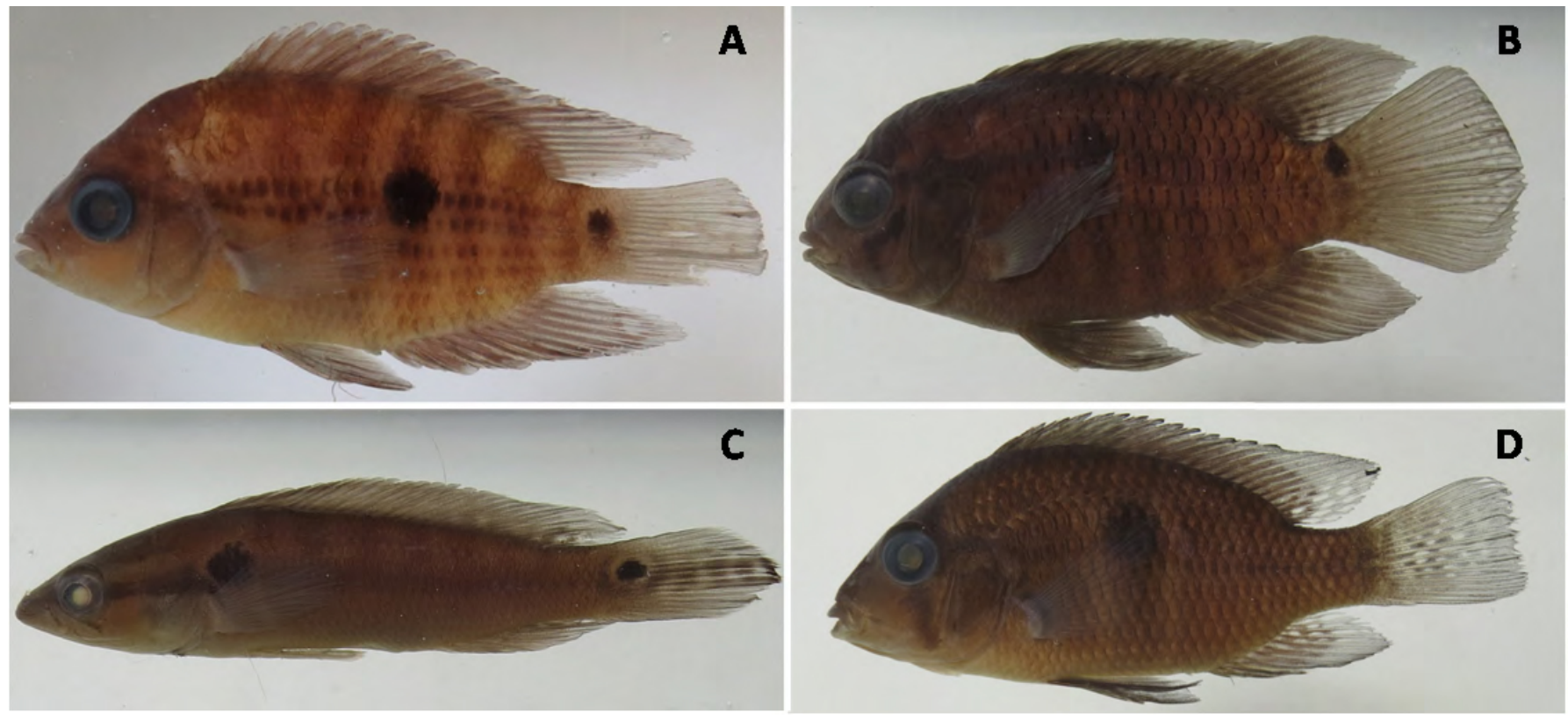

Figure 5. Species of fishes of the Parque Estadual de Itapeva, Rio Grande do Sul state, Brazil. (A) Australoheros cf. facetus, $47.1 \mathrm{~mm} \mathrm{SL,} \mathrm{MCN} \mathrm{18459;} \mathrm{(B)}$ Cichlasoma portalegrense, 45.0 mm SL, MCN 18487; (C) Crenicichla lepidota, 51.3 mm SL, MCN 18460; (D) Geophagus brasiliensis, $55.3 \mathrm{~mm} \mathrm{SL,} \mathrm{MCN} \mathrm{18463.}$

(Říĉan and Kullander 2008) and can be distinguished from its congeners by the presence of six anal-fin spines, four abdominal bars, well developed caudal-fin spot, and gray ground color. According to Ríćan and Kullander (2008) the coastal populations from southern Brazil are different from $A$. facetus by the color pattern and a combination of meristic characters.

Cichlasoma portalegrense (Hensel, 1870): Figure 5B Acara portalegrense Hensel (1870): 52.

Cichlasoma portalegrense (Hensel, 1870). — Malabarba et al. (2013): 121.

Material examined: Table 2

It can be distinguished from Australoheros cf. facetus, a very similar species, by the presence of three anal-fin spines versus six (

Crenicichla lepidota Heckel, 1840: Figure 5C

Crenicichla lepidota Heckel (1840): 429. — Lucena and Kullander (1992): 101; Malabarba et al. (2013): 122.

Material examined: Table 2

\section{Geophagus brasiliensis (Quoy \& Gaimard, 1824):}

\section{Figure 5D}

Chromis brasiliensis Quoy \& Gaimard (1824): 266.

Geophagus brasiliensis (Quoy \& Gaimard, 1824). — Malabarba et al. (2013): 124.

\section{Material examined: Table 2}

\section{DISCUSSION}

The total number of freshwater fish species in the Rio Mampituba basin is still unclear, but according to Malabarba et al. (2013) and Bertaco et al. (2016) about 70 species occur in this basin. Based on the results of this inventory, the fish diversity in the watercourses of PEVA is relatively high, comprising $37 \%$ (26 species) of the total number of freshwater species estimated for the Rio Mampituba basin. On the other hand, all species recorded in the PEVA are also found in the rio Tramandaí system (Malabarba et al. 2013). This sharing of species is congruent with the freshwater ecoregion TramandaíMampituba recognized by Abell et al. (2008).

According to Vari and Malabarba (1998), Castro (1999) and Lowe-McConnell (1999), the predominance of Characiformes and Siluriformes seems to be a trend for Neotropical rivers, a condition supported in this study with a predominance of Characiformes. The low number of Siluriforms in the catches may be due to the characteristics of the area sampled, such as the absence of rocky substrate, since the bottom is constituted mainly of mud and sand, low current, and abundant aquatic vegetation.

Among the endangered species found in PEVA, Atlantirivulus riograndensis and Gymnotus refugio are in the category "Endangered" mainly due to its restricted area of distribution and the loss and degradation of their habitats. These species prefer the shallowest parts of small streams, swamps and flooded areas located usually at the border of marshy forest. The species categorized as "Near Threatened", Mimagoniates rheocharis, is usually found in lentic environment or slow flowing small streams with clear water in the Atlantic Forest, between southern Santa Catarina and northeastern Rio Grande do Sul states. The species is in this category mainly due to deforestation, water pollution and changes in headwaters, resulting in loss and degradation of habitat. According to Colombo et al. (2008), the main threats in the area of PEVA are forest drainage, habitat fragmentation, and wetland degradation.

The high congruence of the ichthyofauna of PEVA with those of the Mampituba and Tramandaí Rivers, 
as well as the presence of threatened species, reinforces the importance of preservation of the conservation unit in the Atlantic Forest biome.

\section{ACKNOWLEDGEMENTS}

We thank to P. Colombo for preparing the map; to E. Borsatto, F. Becker, P. Colombo, R. Hirano, and T. Aguzzoli for their help in the field trip; R. Valim by photograps of the sampling sites; F. R. Carvalho by comments and observations on this paper, and FZBRS by financial support.

\section{LITERATURE CITED}

Abell, R., M.L. Thieme, C. Revenga, M. Bryer, M. Kottelat, N. Bogutskaya, B. Coad, N. Mandrak, S. Contreras Balderas, W. Bussing, M.L.J. Stiassny, P. Skelton, G.R. Allen, P. Unmack, A. Naseka, R. Ng, N. Sindorf, J. Robertson, E. Armijo, J.V. Higgins, T.J. Heibel, E. Wikramanayake, D. Olson, H.L. López, R.E. Reis, J.G. Lundberg, M.H. Sabaj-Pérez and P. Petry. 2008. Freshwater Ecoregions of the World: A new map of biogeographic units for freshwater biodiversity conservation. BioScience 58(5): 403-414. doi: 10.1641/B580507

Albert, J.S. and W.G.R. Crampton. 2003. Seven new species of the neotropical electric fish Gymnotus (Teleostei, Gymnotiformes) with a redescription of G. carapo (Linnaeus). Zootaxa, 287: 1-54.

Azevedo, M.A., C.B. Fialho and L.R. Malabarba. 2016. Reproductive strategies in two inseminating species of Glandulocaudini, Mimagoniates microlepis and Mimagoniates rheocharis (Characiformes: Characidae: Stevardiinae). Journal of Fish Biology 89(1): 431-444. doi: 10.1111/jfb.12876

Bertaco, V.A. and A.R. Cardoso. 2005. A new species of Microglanis (Siluriformes: Pseudopimelodidae) from the rio Uruguay drainage, Brazil. Neotropical Ichthyology 3(1): 61-67. doi: 10.1590/S1679-62252005000100002

Bertaco, V.A., J. Ferrer, F.R. Carvalho and L.R. Malabarba. 2016. Inventory of the freshwater fishes from a densely collected area in South America - a case study of the current knowledge of Neotropical fish diversity. Zootaxa 4138 (3): 401-440. doi: http://doi.org/10.11646/zootaxa.4138.3.1

Bloch, M.E. 1794. Naturgeschichte der ausländischen Fische. Berlim: auf Kosten des Verfassers und in Commission bei dem Buchhändler Hr. Hesse, v. 8. 174 pp.

Bloch, M.E. 1795. Naturgeschichte der ausländischen Fische. Berlim: auf Kosten des Verfassers und in Commission bei dem Buchhändler Hr. Hesse, v. 9. 192 pp.

Bonato, K.O. and J. Ferrer. 2013. New record and distribution extension of Phalloceros spiloura Lucinda, 2008 (Cyprinodontiformes: Poeciliidae). Check List 9(6): 1545-1547. doi: 10.15560/9.6.1545

Boulenger, G.A. 1887. Descriptions of new South-American characinoid fishes. Annals and Magazine of Natural History (Series 5) 19(111): 172-174. doi: 10.1080/00222938709460224

Boulenger, G.A. 1891. An account of the siluroid fishes obtained by Dr. H. von Ihering and Herr Sebastian Wolff in the province Rio Grande do Sul, Brazil. Proceedings of the Zoological Society of London 1891(2): 231-235.

Carvalho, F.R. 2006. Taxonomia das populações de Hyphessobrycon boulengeri (Eigenmann, 1907) e Hyphessobrycon reticulatus Ellis, 1911 (Characiformes: Characidae). Biota Neotropica 6(2): 1.

Castro, R.M.C. 1999. Evolução da ictiofauna de riachos sul-americanos: padrões gerais e possíveis processos casuais; pp. 139-155, in: E.P. Caramaschi, R. Mazzoni, C.R.S.F. Bizerril and P.R. Peres-Neto (eds.). Ecologia de peixes de riachos: estado atual e perspectivas. Rio de Janeiro: Oecologia.
Colombo, P., A. Kindel, G. Vinciprova and L. Krause. 2008. Composição e ameaças à conservação dos anfíbios anuros do Parque Estadual de Itapeva, município de Torres, Rio Grande do Sul, Brasil. Biota Neotropica 8(3): 229-240. doi: 10.1590/S167606032008000300020

Cope, E.D. 1894. On the fishes obtained by the Naturalist Expedition in Rio Grande do Sul. Proceedings of the American Philosophical Society 33: 84-108.

Costa, W.J.E.M. and L.E.K. Lanés. 2009. Rivulus riograndensis, a new aplocheiloid killifish from southern Brazil (Cyprinodontiformes: Rivulidae). Ichthyological Exploration of Freshwaters 20 (1): 91-95.

Eigenmann, C.H. and F. Ogle. 1907. An annotated list of characin fishes in the United States National Museum and the Museum of Indiana University, with descriptions of new species. Proceedings of the United States National Museum 33(1556): 1-36. doi: 10.5479/si.00963801.33-1556.1

Favorito, S.E., A.M. Zanata and M.I. Assumpção. 2005. A new Synbranchus (Teleostei, Synbranchiformes: Synbranchidae) from ilha de Marajó, Pará, Brazil, with notes on its reproductive biology and larval development. Neotropical Ichthyology 3(3): 319-328. doi: 10.1590/S1679-62252005000300001

Ferraris, C.J. 2007. Checklist of catfishes, recent and fossil (Osteichthyes: Siluriformes), and catalogue of siluriform primary types. Zootaxa 1418: 1-628.

Garavello, J.C., H.A. Britski and S.A. Schaefer. 1998. Systematics of the genus Otothyris Myers 1927, with comments on geographic distribution (Siluriformes: Loricariidae: Hypoptopomatinae). American Museum Novitates 3222: 1-19.

Garutti, V. and H.A. Britski. 2000. Descrição de uma espécie nova de Astyanax (Teleostei: Characidae) da bacia do alto rio Paraná e considerações sobre as demais espécies do gênero na bacia. Comunicações do Museu de Ciências e Tecnologia da PUCRS, Série Zoologia 13: 65-88.

Giora, J. and L.R. Malabarba. 2009. Brachyhypopomus gauderio, new species, a new example of underestimated species diversity of electric fishes in the southern South America (Gymnotiformes: Hypopomidae). Zootaxa 2093: 60-68.

Giora, J. and L.R. Malabarba. 2016. Gymnotus refugio, a new and endangered species of electric fish of the Gymnotus pantherinus species-group from southern Brazil (Gymnotiformes: Gymnotidae). Zootaxa 4066 (5): 581-590. doi: 10.11646/ zootaxa.4066.5.6

Heckel, J.J. 1840. Johann Natterer's neue Flussfische Brasilien's nach den Beobachtungen und Mittheilungen des Entdeckers beschrieben (Erste Abtheilung, Die Labroiden). Annalen des Wiener Museums der Naturgeschichte 2: 325-471.

Hensel, R. 1868. Beiträge zur Kenntniss der Wirbelthiere Südbrasiliens. (Fortsetzung). Archiv für Naturgeschichte 34(1): 323-375.

Hensel, R. 1870. Beiträge zur Kenntniss der Wirbelthiere Südbrasiliens. (Fortsetzung). Archiv für Naturgeschichte 36(1): 50-91.

Jenyns, L. 1842. Fish; pp. 1-172, in: C.R. Darwin (ed.). The zoology of the voyage of H. M. S. Beagle, under the command of Captain Fitzroy, R. N., during the years 1832 to 1836 . London: Smith, Elder, and Co.

Lima, F.C.T, L.R. Malabarba, P.A. Buckup, J.F. Pezzi da Silva, R.P. Vari, A. Harold, R. Benine, O.T. Oyakawa, C.S. Pavanelli, N.A. Menezes, C.A.S. Lucena, M.C.S.L. Malabarba, Z.M.S. Lucena, R.E. Reis, F. Langeani, L. Casatti, V.A. Bertaco, C. Moreira and P.H.F. Lucinda. 2003. Genera incertae sedis in Characidae; pp. 134-141, in: R.E. Reis, S.O. Kullander and C.J. Ferraris (eds.). Check List of the Freshwater Fishes of South and Central America. Porto Alegre: Edipucrs.

Linnaeus, C. 1758. Systema Naturae, Ed. X. (Systema naturae per regna tria naturae, secundum classes, ordines, genera, species, cum characteribus, differentiis, synonymis, locis. Tomus I. Editio 
decima, reformata). Holmiae 1: 1-824.

López, R.B. andH.P.Castello.1966.Eigenmanniatrilineata (Teleostomi, Sternopyginae) nueva especie hallada en el Rio de la Plata. Comunicaciones del Museo Argentino de Ciencias Naturales "Bernardino Rivadavia" e Instituto Nacional de Investigación de las Ciencias Naturales, Zoológia, Buenos Aires 4(2): 7-12.

Lowe-Mcconnell, R.H. 1999. Estudos ecológicos em comunidades de peixes tropicais: EDUSP. $534 \mathrm{pp}$.

Lucena, C.A.S. and H.G. Soares. 2016. Review of species of the Astyanax bimaculatus "caudal peduncle spot" subgroup sensu Garutti \& Langeani (Characiformes, Characidae) from the rio La Plata and rio São Francisco drainages and coastal systems of southern Brazil and Uruguay. Zootaxa 4072(1): 101-125. doi: 10.11646/zootaxa.4072.1.5

Lucena, C.A.S. and S.O. Kullander. 1992. The Crenicichla (Teleostei: Cichlidae) species of the Uruguai River drainage in Brazil. Ichthyological Exploration of Freshwaters 3(2): 97-160.

Lucena, C.A.S., J. B. Castro and V.A. Bertaco. 2013. Three new species of Astyanax from drainages of southern Brazil (Characiformes: Characidae). Neotropical Ichthyology 11(3): 537-552. doi: 10.1590/S1679-62252013000300007

Lucinda, P.H.F. 2008. Systematics and biogeography of the genus Phalloceros Eigenmann, 1907 (Cyprinodontiformes: Poeciliidae: Poeciliinae), with the description of twenty-one new species. Neotropical Ichthyology 6(2): 113-158. doi: 10.1590/S167962252008000200001

Lütken, C.F. 1875. Characinae novae Brasiliae centralis a clarissimo J. Reinhardt in provincia Minas-Geraes circa oppidulum Lagoa Santa in lacu ejusdem nominis, flumine Rio das Velhas et rivulis affluentibus collectae, secundum characteres essentiales breviter descriptae. Oversigt over det Kongelige Danske Videnskabernes Selskabs Forhandlinger og dets Medlemmers Arbeider (Kjøbenhavn) 1874(3): 127-143.

Malabarba, L.R. and J.K.F. Mahler. 1998. Review of the genus Microglanis in the rio Uruguay and coastal drainages of southern Brazil (Ostariophysi: Pimelodidae). Ichthyological Exploration of Freshwaters 9(3): 243-254.

Malabarba, L.R., P.C. Neto, V.A. Bertaco, T.P. Carvalho, J.F. dos Santos and L.G.S. Artioli. 2013. Guia de identificação dos peixes da bacia do rio Tramandaí: Via Sapiens. 140 pp.

Meinken, H. 1933. Ueber einige, in letzter Zeit eingeführte Fische II. Blätter für Aquarien- und Terrarienkunde 44(5): 71-73.

Menezes, N.A. and S.H. Weitzman. 1990. Two new species of Mimagoniates (Teleostei: Characidae: Glandulocaudinae), their phylogeny and biogeography and a key to the glandulocaudin fishes of Brazil and Paraguay. Proceedings of the Biological Society of Washington 103(2): 380-426.

Menezes, N.A., S.H. Weitzman, O.T. Oyakawa, F.C.T. Lima, R.M.C. Castro and M.J. Weitzman. 2007. Peixes de água doce da Mata Atlântica: lista preliminar das espécies e comentários sobre conservação de peixes de água doce neotropicais: Museu de Zoologia, USP. 408 pp.
Miquelarena, A.M., R.C. Menni, H.L. López and J.R. Casciotta. 1980. Descripcion de Hyphessobrycon igneus sp. nov. (Characidae Tetragonopterinae) y nuevas localidades para peces de agua dulce de la republica Argentina. III. Neotropica (La Plata) 26(76): 237-245.

Oyakawa, O.T. and G.M.T. Mattox. 2009. Revision of the Neotropical trahiras of the Hoplias lacerdae species-group (Ostariophysi: Characiformes: Erythrinidae) with descriptions of two new species. Neotropical Ichthyology 7(2): 117-140. doi: 10.1590/ S1679-62252009000200001

Quoy, J.R.C. and J.P. Gaimard.1824. Description des Poissons; pp. 1-328, in: L. Freycinet (ed.). Voyage autour du Monde ... exécuté sur les corvettes de L. M. "L'Uranie" et "La Physicienne," pendant les années 1817, 1818, 1819 et 1820. Paris: Pillet aîné.

Reis, R.E., S.O. Kullander and C.J. Ferraris. 2003a. Check List of the Freswater Fishes of South and Central America: Edipucrs. 729 pp.

Reis, R.E., Z.M.S. Lucena, C.A.S. Lucena and L.R. Malabarba. 2003b. Peixes; pp. 117-145, in: C.S. Fontana, G.A. Bencke and R.E. Reis (eds.). Livro vermelho da fauna ameaçada de extinção no Rio Grande do Sul. Porto Alegre: Edipucrs.

Řícan, O. and S.O. Kullander. 2006. Character- and tree-based delimitation of species in the 'Cichlasoma' facetum group (Teleostei, Cichlidae) with the description of a new genus. Journal of Zoological Systematics and Evolutionary Research 44(2): 136-152.

Říĉan, O. and S.O. Kullander. 2008. The Australoheros (Teleostei: Cichlidae) species of the Uruguay and Paraná River drainages. Zootaxa 1724: 1-51.

Silfvergrip, A.M.C. 1996. A systematic revision of the neotropical catfish genus Rhamdia (Teleostei, Pimelodidae) [M.Sc. dissertation]. Stockholm University. 156 pp.

Steindachner, F. 1877. Die Süsswasserfische des südöstlichen Brasilien (III). Sitzungsberichte der Kaiserlichen Akademie der Wissenschaften. Mathematisch-Naturwissenschaftliche Classe 74(1): 559-694.

Vari, R.P. and L.R. Malabarba. 1998. Neotropical ichthyology: an overview; pp. 1-12, in: L.R. Malabarba, R.E. Reis, R.P. Vari, Z.M.S. Lucena and C.A.S. Lucena (eds.). Phylogeny and classification of Neotropical fish. Porto Alegre: Edipucrs.

Wiley, E.O. and G.D. Johnson. 2010. A teleost classification based on monophyletic groups; pp. 123-182, in: J.S. Nelson, H.P. Schultze and M.V.H. Wilson (eds.). Origin and Phylogenetic Interrelationships of Teleosts. München, Germany: Verlag Dr. Friedrich Pfeil.

Author contributions: MAA and VAB analyzed the data and wrote the manuscript; MAA collected the fishes, and VAB identified the species.

Received: 19 February 2016

Accepted: 2 July 2016

Academic Editor: Bárbara Calegari 